\title{
METHODS FOR MODELING ECOSYSTEM SERVICES: A REVIEW
}

\author{
Horea, OLOSUTEAN \\ „Lucian Blaga” University of Sibiu, Romania, mesaje.facultate@yahoo.com
}

\begin{abstract}
Modeling ecosystem services (ES) is an essential tool for the development of strategies that will ensure their future supply, provision and quantification. Given the rapid development in this area of research, a review of the different approaches used to model ES was performed, using an analytical framework based on five criteria for comparing the existing methodological approaches: the types of ES, availability of data sources, spatial scale, types of models used and the possible outcomes of the models. Regulating services were the most commonly modeled, followed by provisioning, cultural, and supporting services. The most frequently used data for modeling were secondary data (already available from scientific literature or data banks). Most studies were performed at the regional or at a global scale. Mechinicist models, based on state and flow equations, were the most commonly used method, but the survey showed a relatively homogeneous distribution of all the identified types of modeling. The synthesis reveals that the majority of studies are based on secondary data, applied at broad scales, without validation techniques, similar to the existing information regarding the mapping of ESs.
\end{abstract}

KEY WORDS: ecosystem services; Millennium Ecosystem Assessment; social-ecological data; spatial scales; models

\section{INTRODUCTION}

The Millennium Ecosystem Assessment defined ecosystem services (ES) or the services generated by the functions of ecosystems as theoretical concept, although they were implicitly discussed and analyzed by ecologists and environmental experts a long time before (Harrison and Hester, 2010). In that order, ecosystems are considered to provide the human society a series of services, classified as provisioning, regulating, supporting and cultural services.

The development of international initiatives such as the MA (2003) or the UNEP Intergovernmental Platform on Biodiversity and Ecosystem Services (IPBES) highlights the increasing need to synthesize information around ESs for balancing human well-being with the maintenance of critical ecological processes (Perrings et al. 2011).

Scientific efforts regarding the quantification, classification and mapping of ecosystem services are increasing in number in the last years, and consistent reviews are already made in the scientific literature (Fleskens and Hubacek, 2013; Martínez Harms and Balvanera, 2012; Vigerstol and Aukema, 2011; Volk, 2013). On the other hand, the construction of mathematical models of ecosystem services and of their relations with various parameters is a relatively new approach, with various paper published in the last few years, and a systematization of the existing information in the field is highly needed.

In this work, I reviewed studies that have modeled ES supply based on social-ecological data. In particular, I (i) identified what type of ES were modeled, (ii) identified the types of sources of information that were used in modeling ES, (iii) identified the spatial scales at which ES were modeled, and (iv) classified the types of methods used to model ESs under the social-ecological approach. I concluded by discussing the advantages and disadvantages of the types of methodological approaches to model ES.

\section{METHODS}

\subsection{Definitions and scope}

ESs are components of ecosystems that are directly consumed and enjoyed, or that contribute to human well-being conditions through interactions with other components, for example, climate regulation or erosion.

Two approaches are mainly used in scientific studies: ES supply, or the full potential of ecological functions or biophysical elements in an ecosystem to provide a potential ES, which is the focus of most studies to date, and ES provision, determined by the rate human society consumes the supply, much less often studies, but of equal importance from this review's point of view.

\subsection{Sources of information}

I identified all peer review publications about ES modeling using the electronic databases of the Web of Science ISI Web of knowledge, Science Direct, and Google Scholar. The following keywords were used, either alone or in combination: „ecosystem services”, „modeling ecosystem services”, „ecosystem function”, „ecosystem process”, „ecosystem value". A total of 63 publications published from 1998 to 2015 were identified that have modeled ES. To focus solely on these publications that constructed mathematical models of ES, 14 studies that presented frameworks for further models were excluded from the analysis.

The remaining 47 studies (Figure 1) that modeled ES supply and provision were further analyzed using five criteria for comparison among approaches, based on the methodology presented by Martínez-Harms and Balvanera (2012) (Table 1), 
individual entries for each of the ES modeled in each of these studies being used.

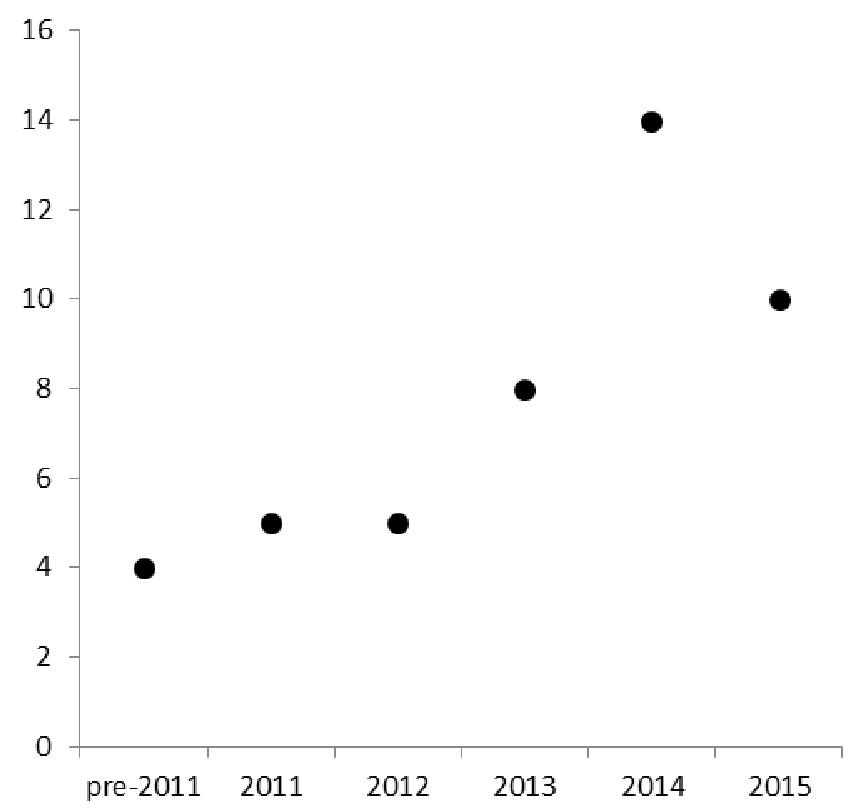

Figure 1. Number of studies that modeled ESs.

The MA classification (2003) of ES into supporting, regulating, provisioning, and cultural services was used for the differentiation among the investigated studies. I identified the spatial scale as the total extent of the area from which the information was gathered for modeling.

We then described the methods for modeling ES, mainly the way in which the information was compiled and processed, and classified them into five categories. The first category is the use of state and flow equation between the parts of the system viewed as individual entities, using ,mechanicist models”. The second approach corresponds to ,probabilistic models", in which cybernetic information, such as Bayesian Belief Networks, decision trees or Expert Knowledge are used for prognosis and estimation of ES. The third one is a "statistical” approach, in which statistical tests, correlations and regression are used.

The fourth approach is called „GIS-based models", where prognosis and estimation is based on the use of different GIS modules that process the information. The fifth category is called „conceptual models”, using information from different types of models presented above and the way to relate the heterogeneous modeling information.

Table 1. Criteria used to classify the types of approaches used in modeling ES (adapted after Martínez-Harms and Balvanera, 2012).

\begin{tabular}{|c|c|c|}
\hline Criteria & Categories considered & Rationale \\
\hline \multirow[t]{4}{*}{ Types of ESs } & Cultural & $\begin{array}{l}\text { Tangible and intangible benefits derived from the relationship between } \\
\text { man and the ecosystem, such as recreation, scenic beauty, and so on }\end{array}$ \\
\hline & Provisioning & Products obtained from ecosystems, such as water, food, fiber, etc. \\
\hline & Regulating & $\begin{array}{l}\text { Emergent properties of ecosystems that regulate the environmental } \\
\text { conditions in which human beings live (e.g., climate regulation, } \\
\text { hydrological cycles, water quality) }\end{array}$ \\
\hline & Supporting & $\begin{array}{l}\text { Basic ecosystem processes that maintain the generation of all other } \\
\text { services (e.g., soil formation, pollination, nutrient cycling) }\end{array}$ \\
\hline \multirow[t]{3}{*}{ Availability of data sources } & Primary data & $\begin{array}{l}\text { Information derived from sampling in the field (e.g., field data, surveys, } \\
\text { or interviews or census data) }\end{array}$ \\
\hline & Secondary data & $\begin{array}{l}\text { Information derived from readily available information not verified in the } \\
\text { field (e.g., cartographical data, remote-sensed data, socioeconomic data, } \\
\text { and mixed sources like databases like global statistics) }\end{array}$ \\
\hline & Simulated data & $\begin{array}{l}\text { Information generated by the researcher in order to prove the viability and } \\
\text { usability of the model }\end{array}$ \\
\hline \multirow[t]{5}{*}{ Scale } & Patch & $10-10^{2} \mathrm{~km}^{2}$ \\
\hline & Local & $10^{2}-10^{3} \mathrm{~km}^{2}$ \\
\hline & Regional & $10^{3}-10^{5} \mathrm{~km}^{2}$ \\
\hline & National & $10^{5}-10^{6} \mathrm{~km}^{2}$ \\
\hline & Global & $>10^{6} \mathrm{~km}^{2}$ \\
\hline \multirow[t]{5}{*}{ Model } & & $\begin{array}{l}\text { Use of state and flow equation between the parts of the system viewed as } \\
\text { individual entities }\end{array}$ \\
\hline & Probabilistic & $\begin{array}{l}\text { Use of Bayesian Belief Networks, Expert Knowledge or other forms of } \\
\text { Artificial Intelligence to transform existing information into future } \\
\text { prognosis }\end{array}$ \\
\hline & Statistical & Use of field data of ESs as response variables \\
\hline & GIS-based & $\begin{array}{l}\text { Use of GIS modules for integration of field data into prognosis and } \\
\text { estimation maps }\end{array}$ \\
\hline & Conceptual & $\begin{array}{l}\text { Use of information from different types of models presented above and } \\
\text { the way to relate the heterogeneous modeling information }\end{array}$ \\
\hline Model outcomes & $\begin{array}{l}\text { Prognosis } \\
\text { Quantification/estimation }\end{array}$ & $\begin{array}{l}\text { Estimation of a future value starting from present day data } \\
\text { Estimation of the total value starting from discrete data }\end{array}$ \\
\hline
\end{tabular}




\section{RESULTS AND DISCUSSION}

\subsection{Ecosystem services modeled}

I found 47 studies modeling ES based on social-ecological data; considering each ES modeled within each reference, the database had 105 entries. A detailed list of the literature studied is presented in Appendix 1.

Fourteen different ESs have been modeled to date (Figure 2). The most commonly mapped services are water provision, food production, carbon storage and cultural services, from a general point of view. Regulating services were the most commonly modeled services, followed by provisioning, supporting, and cultural services.

\subsection{Types of models}

Mechanicist approaches were the most frequently used in ES modeling $(28.57 \%)$, followed by GIS-based models $(24.49 \%$; Figure 3). However, excepting conceptual models, all the other four types of modeling were relatively homogeneously represented in the studies found in the field.

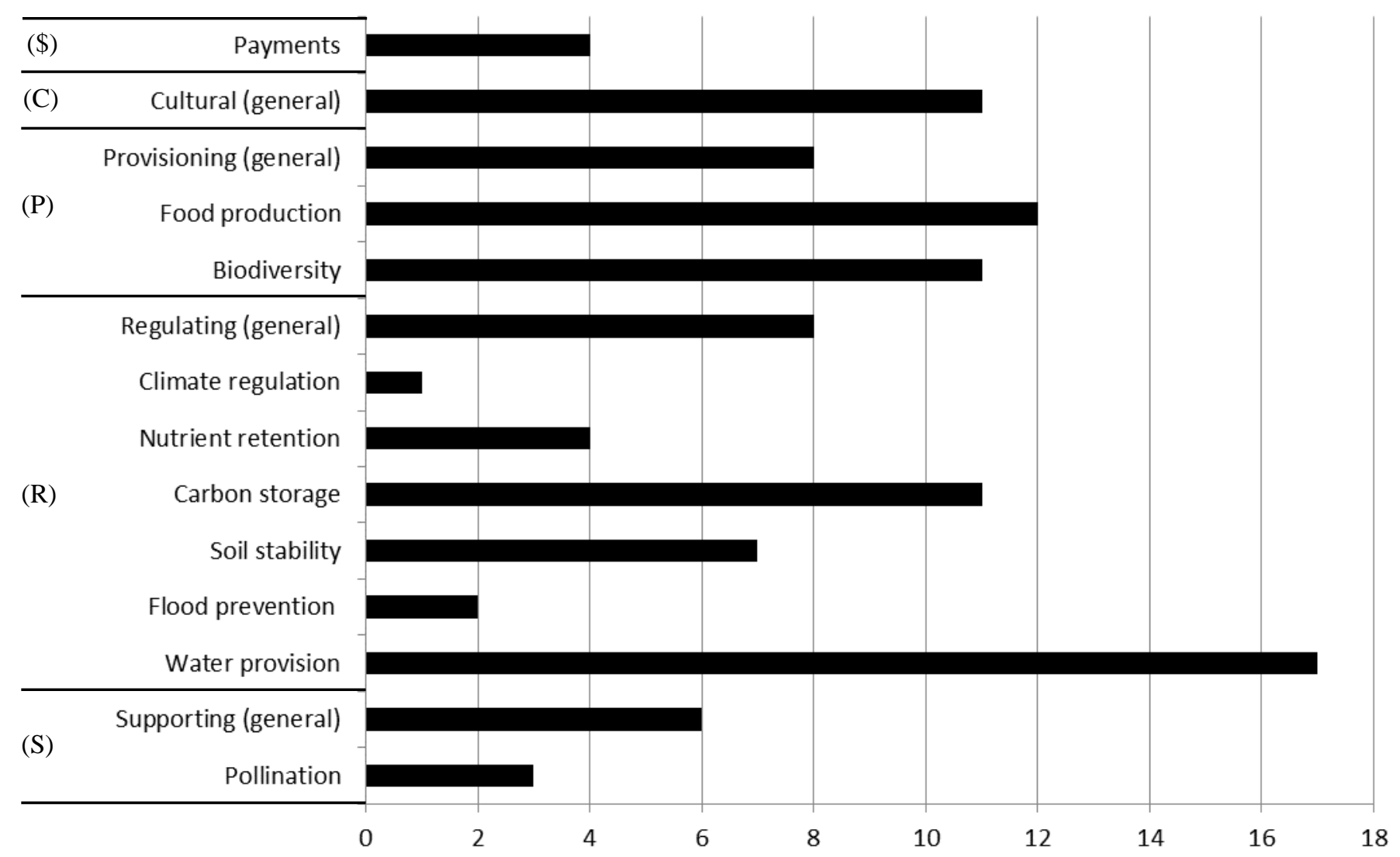

Figure 2. Frequency distribution of studies that modeled ESs (entries correspond to each service within each reference; $\mathrm{S}-$ supporting services; $\mathrm{R}$ - regulating services; $\mathrm{P}$ - provisioning services; $\mathrm{C}$ - cultural services; $\$$ - payments for ecosystem services).

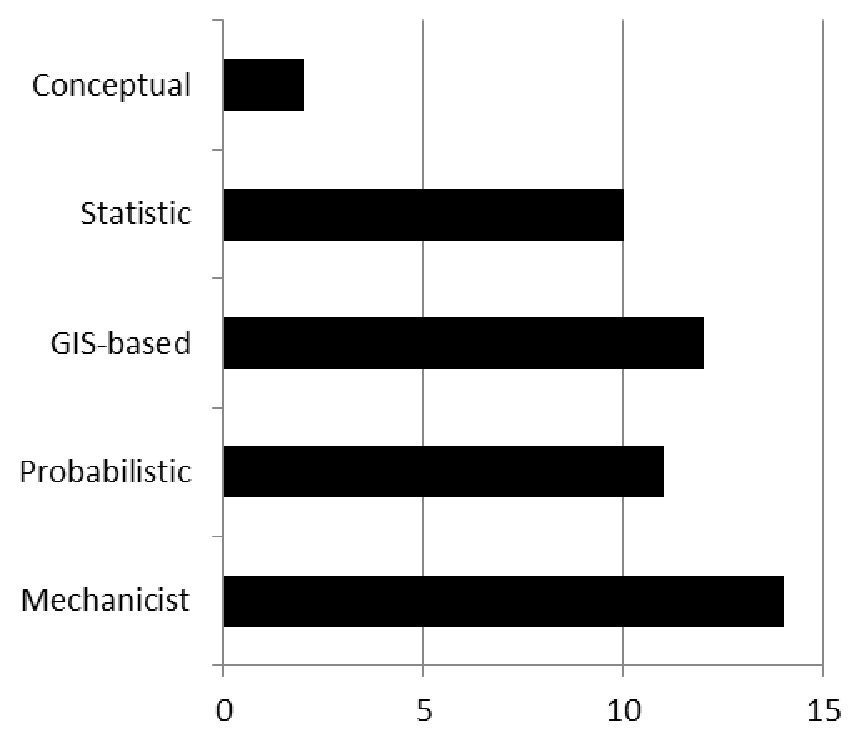

Figure 3. Number of studies that modeled ES.

\subsection{Scale}

Most ES modeling was done at the regional scale $(36.36 \%$ of the entries) closely followed by the global one $(29.54 \%)$, with much fewer studies at the patch, local, and national scales. The global scale was the most common for the four types of ES (Figure 4).

\subsection{Types of data used in modeling}

At a general point of view, secondary data were the most commonly used (48.78\%), as compared to simulated data $(36.26 \%)$ and primary data $(16.26 \%)$ (Figure 5$)$. For the four types of ESs investigated, secondary data was the most used information for regulating and provisioning services, while simulated data was the basis for most of the models regarding cultural and supporting services.

\subsection{Model outcomes}

Prognosis is the main outcome of the generated models regarding ESs, with over $68 \%$ of the models used for anticipating the evolution of ESs starting from known values (Figure 6). The remaining $31.65 \%$ are models that estimate or quantify the complete value of ESs from discrete data available 
to the researchers. The situation applies for each of the four ES categories, cultural services having the most equilibrated ratio between the two categories of model outcomes $(60 \%$ prognosis to $40 \%$ estimation/quantification).

\subsection{Information gaps and future perspectives}

The synthesis reveals an increasing amount of literature regarding the modeling of $\mathrm{ES}$, the number of papers being gradually higher in the last period, with studies in the field already published in 2015 at almost the same number as in the entire 2014, as seen in Figure 1. Despite these advances, the sources of information and modeling methods are highly diverse, and most studies lack detailed methodological information, situation consistent with the findings of MartínezHarms and Balvanera (2012) for mapping ESs.

Some clear trends are also visible, key ESs that are today considered for decision making being frequently modeled, such as carbon storage, food production or water provision. In the same way as for mapping (Martinez-Harms and Balvanera, 2012) ESs that may be critical for the maintenance of ecosystems and human welfare (e.g. primary productivity, disease regulation or cultural services such as identity or scenic beauty), have not been included in this list to date, creating the idea of a lack of interest on many of these services. Other important ESs, such as pollination, climate regulation or flood prevention are rarely addressed.
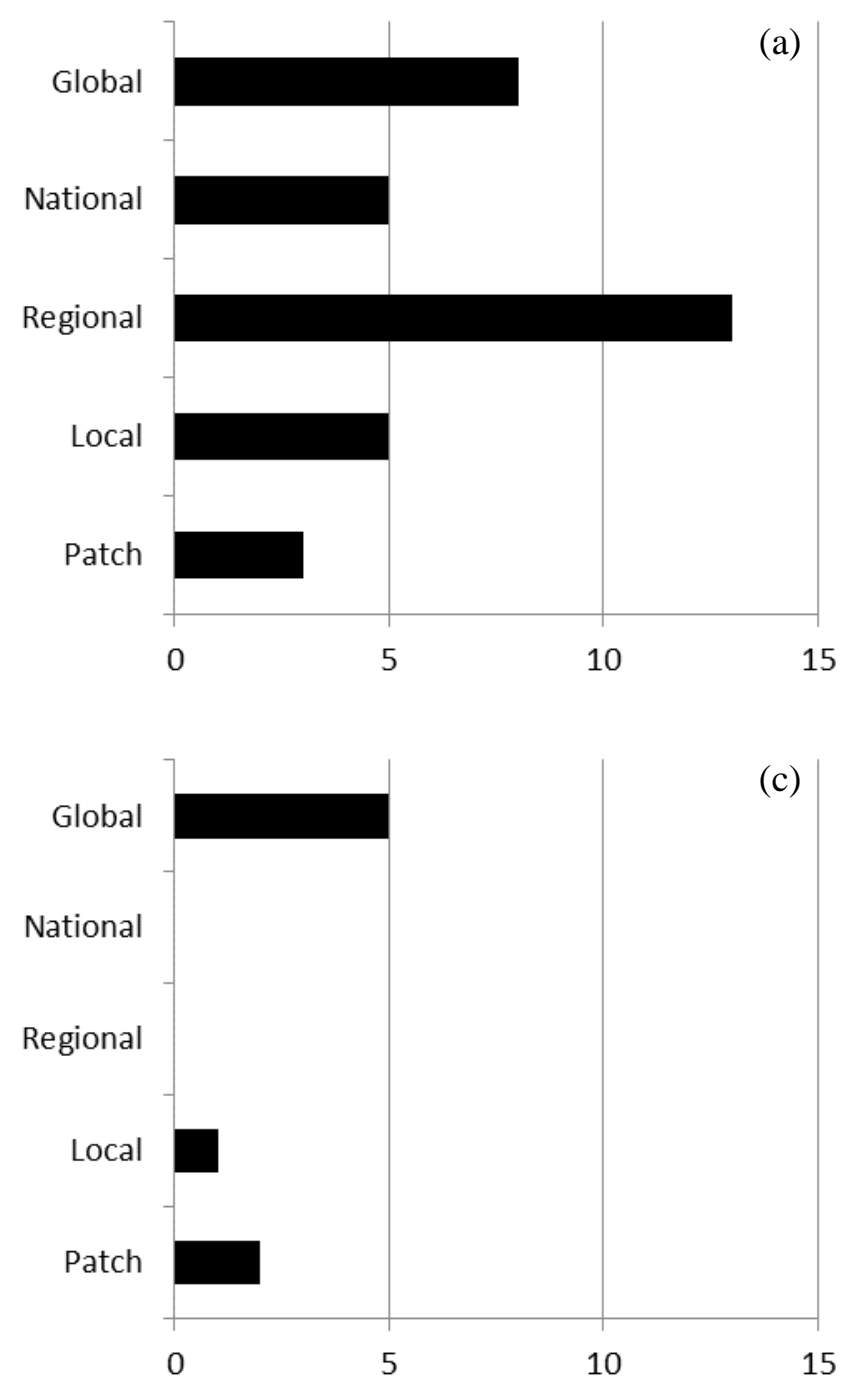

Another important aspect to be observed is the general perspective presented in a consistent part of the analyzed literature, with cultural, provisioning, supporting and regulating services modeled as uniform entities, and not a specific ESs, part of a larger category. Almost a third $(31.43 \%)$ of the entries included in the analysis consists of ESs modeled as an entire category, creating a rather confusing approach, difficult to use in practice for prognosis or quantification.

Even more, the relatively recent experience in the field of modeling ESs generated a large amount of methodologies and not a consistent, coherent approach, with only 2 papers (Sun and Müller, 2012; Smajgl et al., 2015) using more than one modeling technique, given the fact that the data required are heterogeneous and a singular approach is unable to encompass all the information gathered for an integrated approach. From that point of view, a future direction should probably consist of integrating several modeling techniques into larger, more comprehensive models, capable of prognosis and quantification of ESs at a larger scale.

Last but not least, very few of the investigated models refer to payments for ESs and their reflection into the future evolution of the services' quality and quantity, an aspect that should raise a more consistent approach, due to the close relation between public awareness and the conservation of natural capital. Future discussions should also take into consideration this aspect and relate its particularities to the prognosis of ESs.
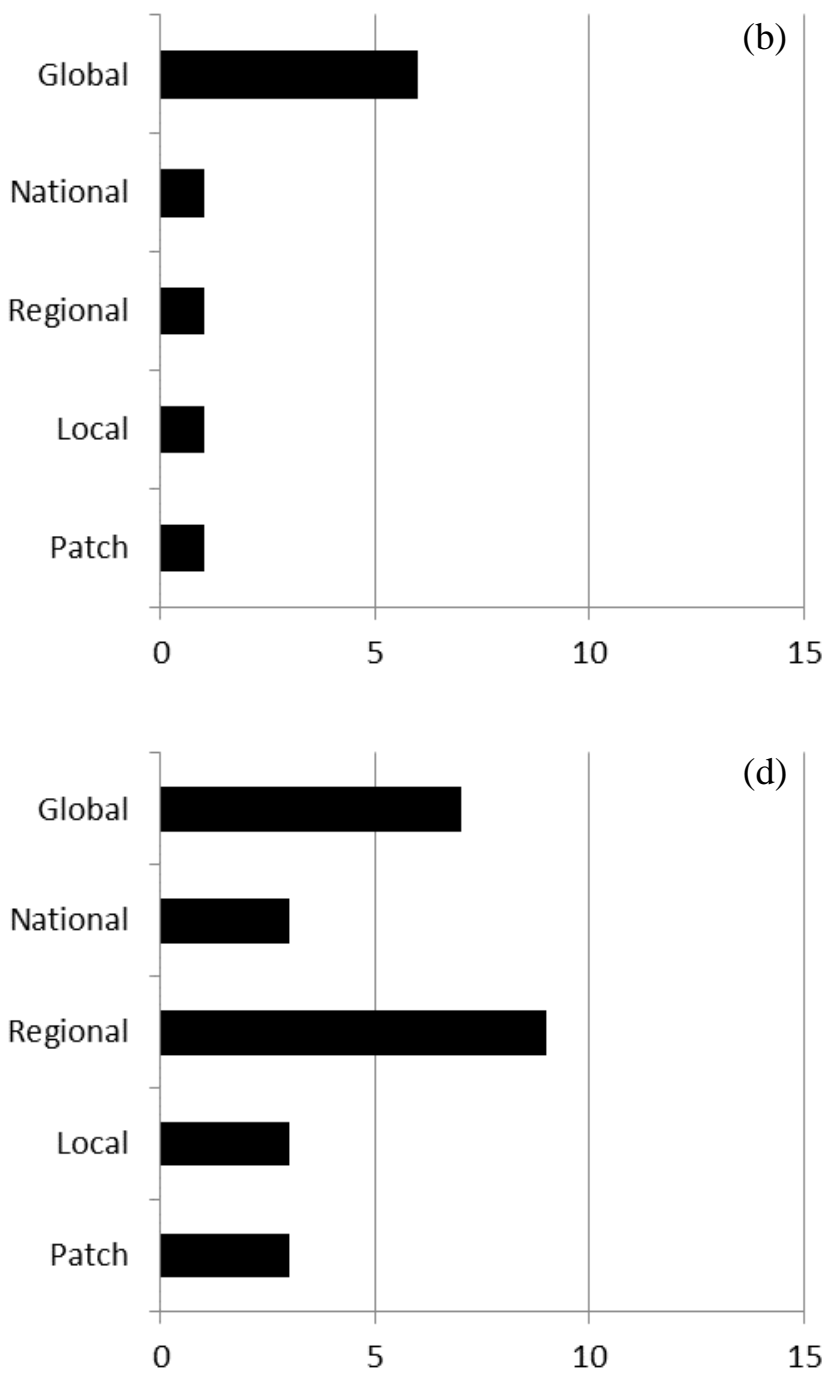

Figure 4. Spatial scales at which ESs have been mapped, for (a) regulating, (b) supporting, (c) cultural, and (d) provisioning ES (scales are the one provided in Table 1). 


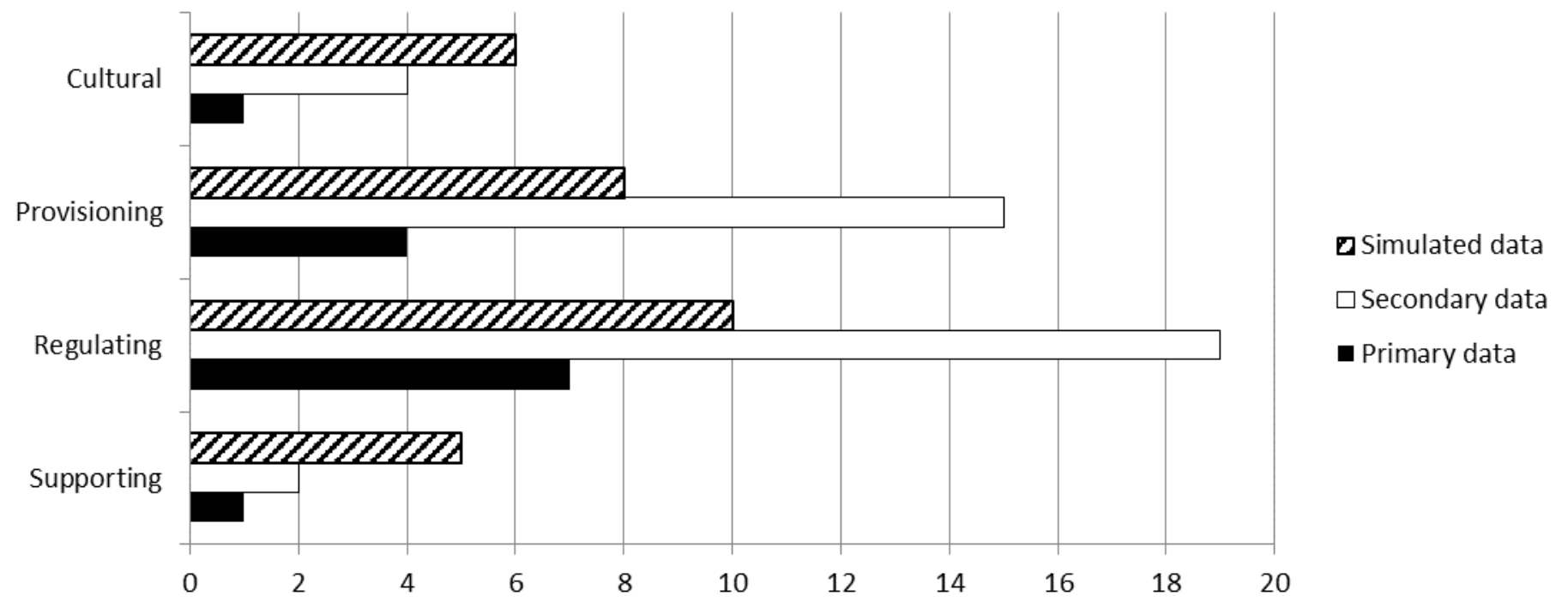

Figure 5. Type of data source of the entries used in the database for different types of ESs.

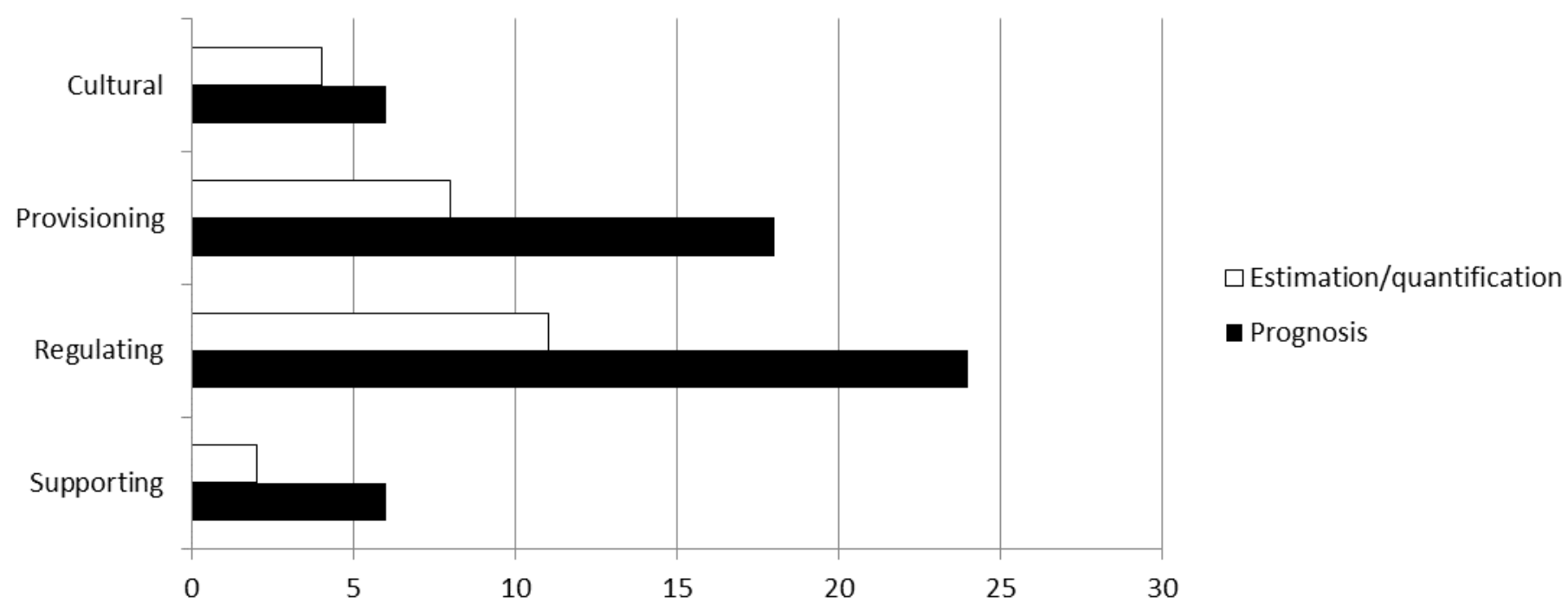

Figure 6. Number of studies that modeled ES.

\section{ACKNOWLEDGEMENTS}

This paper is supported by the Sectorial Operational Program Human Resources Development (SOP HRD), financed from the European Social Fund and by the Romanian Government under the contract number POSDRU/159/1.5/133675.

\section{REFERENCES}

1. Arbault, D., Rivière, M., Rugani, B., Benetto, E., TirutaBarna, L., Integrated earth system dynamic modeling for life cycle impact assessment of ecosystem services, Science of the Total Environment, Vol. 472, pp. 262-272, (2014).

2. Bagstad, K.J., Semmens, D.J., Winthrop, R., Comparing approaches to spatially explicit ecosystem service modeling: A case study from the San Petro River, Arizona, Ecosystem Services, Vol. 5, pp. e40-e50, (2013).

3. Bai, Y., Zheng, H., Ouyang, Z., Zhuang, C, Jiang, B., Modeling hydrological ecosystem services and trade-offs: a case study in Bayiangdian watershed, China, Environmental Earth Sciences, Vol. 70, No. 2, pp. 709718, (2013).

4. Balbi, S., del Prado, A., Gallejones, P., Geevan, C.P., Prado, G., Pérez-Miñana, E., Manrique, R., HernandezSantiago, C., Villa, F., Modelling trade-offs among ecosystem services in agricultural production systems, Environmental Modelling \& Software, in print (2015).

5. Bennet, D.E., Gosnell, H., Integrating multiple perspectives on payments for ecosystem services through a social-ecological systems framework. Ecological Economics, Vol. 116, pp. 172-181, (2015).

6. Boumans, R., Roman, J., Altman, I., Kaufman, L., The Multiscale Integrated Model of Ecosystem Services (MIMES): Simulating the interactions of coupled human and natural systems, Ecosytems Services, Vol. 12, pp. 3041, (2015). 
7. Brady, M., Sahrbacher, C., Kellermann, K., Happe, K., An agent-based approach to modeling impacts of agricultural policy on land use, biodiversity and ecosystem services, Landscape Ecology, Vol. 27, No. 9, pp. 1363-1381, (2012).

8. Brander, L.M., van Beukering, P., Cesar, H.S.J., The recreational value of coral reefs: A meta-analysis, Ecological Economics, Vol. 63, pp. 209-218, (2007).

9. Chen, X., Lupi, F., An, L., Shelly, R., Viña, A., Liu, J., Agent-based modeling of the effects of social norms on enrolment in payments for ecosystem services, Ecological Modelling, Vol. 229, pp. 16-24 (2012).

10. Commelo, S.D., Maltais-Landry, G., Schwegler, B.R., Lepech, M.D., Firm-level ecosystem service valuation using mechanistic biogeochemical modeling and functional substitutability, Ecological Economics, Vol. 100, pp. 63-73, (2014).

11. Connor, J.D., Bryan, B.A., Nolan, M., Stock, F., Gao, L., Dunstall, S., Graham, P., Ernst, A., Newth, D., Grundy, M., Hatfield-Dodds, S., Modelling Australian land use competition and ecosystem services with food price feed backs at high spatial resolution, Environmental Modelling \& Software, Vol. 69, pp. 141-154, (2015).

12. Cordier, M., Perez Agundez, J.A., Hecq, W., Hamaide, B., A guiding framework for ecosystem services monetization in ecological-economical modeling, Ecosystem Services, Vol. 8, pp. 86-96, (2014).

13. Delphin, S., Escobedo, F.J., Abd-Elrahman, A., Cropper, W. Jr., Mapping potential carbon and timber losses from hurricane using a decision tree and ecosystem services driver model, Journal of Environmental Management, Vol. 129, pp. 599-607 (2013).

14. Ding, H., Nunes, P.A.L.D., Modeling the links between biodiversity, ecosystem services and human wellbeing in the context of climate change: Results from an econometric analysis of the European forest ecosystems, Ecological Economics, Vol. 97, pp. 60-73, (2014).

15. Feng, M., Liu, S., Euliss, N.H. Jr., Young, C., Mushet, D.M, Prototyping an online wetland ecosystem services model using open model sharing standards, Environmental Modelling \& Software, Vol. 26, pp. 458-468, (2011).

16. Fleskens, L., Hubacek, K., Modelling land amangement for ecosystem services, Regional Environmental Change, Vol. 13, pp. 563-566, (2013).

17. Gebremariam, S.Y., Martin, J.F., DeMarchi, C., Bosch, N.S., Confesor, R., Ludsin, S.A., A comprehensive approach to evaluating watershed models for predicting flow regimes critical to downstream ecosystem services, Environmental Modelling \& Software, Vol. 61, pp. 121134, (2014).

18. Grêt-Regamey, A., Bebi, P., Bishop, I.D., Schmid, W.A., Linking GIS-based model to value ecosystem services in an Alpine region, Journal of Environmental Management, Vol. 89, pp. 197-208, (2008).

19. Grêt-Regamey, A., Celio, E, Klein, T.M., Wissen Hayek, U., Understanding ecosystem services trade-offs with interactive procedural modelin for sustainable urban planning, Landscape and Urban Planning, Vol. 109, pp.107-116, (2013).

20. Guerra, C.A., Pinto-Correia, T., Metzger, M.J., Mapping soil erosion prevention using an ecosystem service modeling framework for integrated land management and policy, Ecosystems, Vol. 17, No. 5, pp. 878-889 (2014).

21. Guerry, A.D., Ruckelshaus, M.H., Arkema, K.K., Bernhardt, J.R., Guannel, G., Kim, C.-K., Marsik, M.,
Papenfus, M., Toft, J.E., Verutes, G., Wood, S.A., Beck, M., Chan, F., Chan, K.M.A., Gelfenbaum, G., Gold, B.D., Halpern, B.S., Labiosa, W.B., Lester, S.E., Levin, P.S., McField, M., Pinsky, M.L., Plummer, M., Polasky, S., Ruggiero, P., Sutherland, D.A., Tallis, H., Day, A., Spencer, J., Modeling benefits from nature: using ecosystem services to inform coastal and marine spatial planning, International Journal of Biodiversity Science, Ecosystem Services \& Management, Vol. 8, No. 1-2, pp. 107-121 (2012).

22. Guillem, E.E., Murray-Rust, D., Robinson, D.T., Rounsevell, M.D.A., Modelling farmer decision-making to anticipate tradeoffs between provisioning ecosystem services and biodiversity, Agricultural Systems, Vol. 137, pp. 12-23, (2015).

23. Harrison, R.M., Hester, R.E., Ecosystem services, RSC Publishing, London-Cambridge (2010).

24. Harmáčková, Z.V., Vačkár, D., Modelling regulating ecosystem services trade-offs across landscape scenarios in Třeboňsko Biosphere Reserve, Czech Republic, Ecological Modelling, Vol. 295, pp. 207-215, (2015).

25. Hou, Y., Zhou, S., Burkhard, B., Muller, F., Socioeconomic influences on biodiversity, ecosystem services and human well-being: a quantitative application of the DPSIR model in Jiangsu, China, Science of the Total Environment, Vol. 490, pp. 1012-1028, (2014).

26. Johnson, G.W., Snapp, R.R, Villa, F., Bagstad, K., Modelling ecosystem services under uncertainty with Stochastic SPAN, International Congress on Environmental Modelling and Software, Leipzig, Germany, http://www.iemss.org/society/index.php/iemss2012-proceedings (2012).

27. Johnston, J.M., McGarvey, D.J., Craig Barber, M., Laniak, G., Babendreier, J., Parmar, R., Wolfe, K., Kraemer, S.R., Cyterski, M., Knightes, C., Rasleigh, B., Suarez, L., Ambrose, R., An integrated modeling framework for performing environmental assessments: Application to ecosystem servicesin the Albemarle-Pamlico basin (NC and VA, USA), Ecological Modelling, Vol. 222, pp. 24712484, (2011).

28. Keller, A.A., Fournier, E., Fox, J., Minimising impacts of land use change on ecosystem services using multi-criteria heuristic analysis, Journal of Environmental Management, Vol. 156, pp. 23-30, (2015).

29. Koniak, G., Noy-Meir, I., Perevolotsky, A., Modelling dynamics of ecosystem services basket in Mediteraneean landscapes: a tool for rational management, Landscape Ecology, Vol. 26, pp. 109-124, (2011).

30. Larocque, G.R., Bhatti, J., Arsenault, A., Integrated modeling software platform development for effective use of ecosystem models, Ecological Modelling, Vol. 288, pp. 195-202, (2014).

31. Lauf, S., Haase, D., Kleinschmit, B., Linkages between ecosystem services provisioning, urban growth and shrinkage - A modeling approach 10unctiona ecosystem service trade-offs, Ecological Indicators, Vol. 42, pp. 7394, (2014).

32. Locatelli, B., Imbach, P., Vignola, R., Metzger, M.J., Hidalgo, E.J.L., Ecosystem services and hydroelectricity in Central America: modelling service flows with fuzzy logic and expert knowledge, Regional Environmental Change, Vol. 11, pp. 393-404, (2011).

33. Martin-Ortega, J., Ojea, E., Roux, C., Payments for Water Ecosystem Services in Latin America: A literature review 
and conceptual model, Ecosystem Services, Vol. 6, pp. 122-132, (2013).

34. Martínez-Harms, M.J., Patricia Balvanera, P., Methods for mapping ecosystem service supply: a review, International Journal of Biodiversity Science, Ecosystem Services \& Management, Vol. 8, No. 1-2, pp. 17-25, (2012).

35. McVittie, A., Norton, L., Martin-Ortega, J., Siamenti, I., Glenk, K., Aalders, I., Operationalizing an ecosystem service-based approach using Bayesian Belief Networks: An application to riparian buffer strips, Ecological Economics, Vol. 110, pp. 15-27, (2015).

36. Meylan, L., Merot, A., Gary, C., Rapidel, B., Combining a typology and a conceptual model of cropping system to explore the diversity of relationships between ecosystem services: The case of erosion control in coffee-based agroforestry systems in Costa Rica, Agricultural Systems, Vol. 118, pp. 52-64, (2013).

37. Moor, H., Hylander, K, Norberg, J., Predicting climate change effects on wetland ecosystem services using species distribution modeling and plant 11 unctional traits, AMBIO, Vol. 44, Suppl. 1, pp. S113-S126, (2015).

38. Notter, B., Hurni, H., Wiesmann, U., Abbaspour, K.C., Modelling water provision as an ecosystem service in a large East African river basin, Hydrology and Earth System Sciences, Vol. 16, pp. 69-86, (2012).

39. Nuppenau, E.A., Integrated modelling of payment for ecosystem services: using willingness to pay and accept, for nature provision and addressing public management in cultural landscape, Operational Research, Vol. 14, No. 2, pp. 151-175, (2014).

40. Perrings. C., Duraiappah, A., Larigauderie, A., Mooney, H., The biodiversity and ecosystem services science-policy interface, Science, Vol. 331, pp. 1139-1140, (2011).

41. Petz, K., Alkemade, R., Bakkenes, M., Schlup, C.J.E., van der Velde, M., Leemans, R., Mapping and modelling trade-offs and synergies between grazing intensity and ecosystem services in rangelands using global-scale datasets and models, Global Environmental Change, Vol. 29, pp. 223-234, (2014)

42. Poppenborg, P., Koellner, T., A Bayesian network approach to model farmers' crop choice using sociopsychological measurements of expected benefits of ecosystem services, Environmental Modelling \& Software, Vol. 57, pp. 227-234, (2014).

43. Sabatier, R., Meyer, K., Wiegand, K., Clough, Y., Nonlinear effects of pesticide application on biodiversity driven ecosystem services and disservices in a cacao agroecosystem: A modeling study, Basic and Applied Ecology, Vol. 14, pp. 115-125, (2013).

44. Schlüter, M., Leslie, H., Levin, S., Managing water-use trade-offs in a semi-arid river delta to sustain multiple ecosystem 11ervices: A modelling approach, Ecological Research, Vol. 24, pp. 491-503, (2009).
45. Smajgl, A., Xu, J., Egan, S., Yi, Z.F., Ward, J., Su, Y., Assessing the effectiveness of payments for ecosystem services for diversifying rubber in Yunnan, China, Environmental Modelling \& Software, Vol. 69, pp. 187195, (2015).

46. Sun, Z., Müller, D., A framework for modeling payments for ecosystem services with agent-based models, Bayesian Belief Networks and opinion dynamics models, Environmental Modelling \& Software, Vol. 45, pp.15-28, (2013).

47. Swetnam, R.D., Fisher, B., Mbilinyi, B.P., Munishi, P.K.T., Willcock, S., Ricketts, T., Mwakalila, S., Balmford, A., Burgess, N.D., Marshall, A.R., Lewis, S.L., Mapping socio-economic scenarios of land cover change: A GIS method to enable ecosystem service modelling, Journal of Environmental Management, Vol. 92, pp. 563574, (2011).

48. Vigerstol, K.L., Aukema, J.E., A comparison of tools for modeling freshwater ecosystem services, Journal of Environmental Management, Vol. 92, pp. 2403-2409, (2011).

49. Villa, F., Semantically driven meta-modelling: Automatic model construction in an environmental decision support for the assessment of ecosystem services flow, Athanasiadis et al. eds., Information technologies and environmental engineering, Springer Verlag, BerlinHeidelberg, (2009).

50. Volk, M., Modelling ecosystem services - Chalanges and promising future directions, Sustainability of Water Quality and Ecology, Vol. 1-2, pp. 3-9 (2013).

51. Watanabe, M.D.B., Ortega, E., Dynamic emergy accounting of water and carbon ecosystem services: A model to stimulate the impacts of land-use change, Ecological Modelling, Vol. 271, pp. 113-131, (2014).

52. Zanchi, G., Belyazid, S., Akselsson, C., Yu, L., Modelling the effects of management intensification on multiple forest services: a Swedish case study, Ecological Modelling, Vol., 284, pp. 48-59, (2014).

53. Name, Sure-name., Name, Sure-name., Title of the book, $5^{\text {th }}$ edition, Editors eds., City, State, (2009).

54. Name, Sure-name., Name, Sure-name., Name, Sure-name., Title of the article, Publication Name,Vol.5, No.3, pp. 34 41, (2009).

55. Name, Sure-name., Name, Sure-name., Title of the proceedings, Name of the conference, Vol. II, pp. 191-199, City, State, (2009).

56. Fox, T.Q., Dog, T.L., The quick brown fox jumps over the lazy dog, $5^{\text {th }}$ edition, Animals eds., The Forest, (2009).

57. Bear, B., Wolf, A.K., Chasing in the woods, Forest stories, Vol.5, No.3, pp. 34 -41, (2009).

58. Cat, A.-S., Mice, M.O., Cheese, G., Night behaviours, $6^{\text {th }}$ International Conference on the Management of Behavioural Changes, Vol. II, pp. 191-199, City, State, (2009). 
Appendix 1: List of scientific paper presenting modeling approaches of ESs.

\begin{tabular}{|c|c|c|c|}
\hline No. & Authors & Year & Ess modeled \\
\hline 1. & Arbault et al. & 2014 & provisioning, cultural, supporting, regulating \\
\hline 2. & Bagstad et al. & 2013 & provisioning, cultural, regulating \\
\hline 3. & Bai et al. & 2013 & regulating \\
\hline 4. & Balbi et al. & 2015 & provisioning, regulating \\
\hline 5. & Bennet and Gosnell & 2015 & regulating \\
\hline 6. & Boumans et al. & 2015 & regulating \\
\hline 7. & Brady et al. & 2012 & provisioning \\
\hline 8. & Brander et al. & 2007 & cultural \\
\hline 9. & Chen et al. & 2012 & cultural \\
\hline 10. & Connor et al. & 2015 & provisioning, regulating \\
\hline 11. & Commelo et al. & 2014 & provisioning, regulating \\
\hline 12. & Cordier et al. & 2014 & provisioning, cultural, supporting, regulating \\
\hline 13. & Delphin et al. & 2013 & regulating \\
\hline 14. & Ding and Nunes & 2014 & provisioning, cultural, regulating \\
\hline 15. & Feng et al. & 2011 & regulating \\
\hline 16. & Gebremariam et al. & 2014 & regulating \\
\hline 17. & Grêt-Regamey et al. & 2008 & provisioning \\
\hline 18. & Grêt-Regamey et al. & 2013 & regulating \\
\hline 19. & Guerra et al. & 2014 & regulating \\
\hline 20. & Guerry et al. & 2012 & provisioning, cultural, supporting, regulating \\
\hline 21. & Guillem et al. & 2015 & provisioning \\
\hline 22. & Harmáčková and Vačkár & 2015 & regulating \\
\hline 23. & Hou et al. & 2014 & provisioning \\
\hline 24. & Johnson et al. & 2012 & provisioning, cultural, supporting, regulating \\
\hline 25. & Johnston et al. & 2011 & provisioning \\
\hline 26. & Keller et al. & 2015 & provisioning, supporting, regulating \\
\hline 27. & Koniak et al. & 2011 & provisioning, regulating \\
\hline 28. & Larocque et al. & 2014 & provisioning, cultural, supporting, regulating \\
\hline 29. & Lauf et al. & 2014 & provisioning, regulating \\
\hline 30. & Locatelli et al. & 2011 & regulating \\
\hline 31. & Martin-Ortega et al. & 2013 & payments \\
\hline 32. & Meylan et al. & 2013 & regulating \\
\hline 33. & McVittie et al. & 2015 & regulating \\
\hline 34. & Moor et al. & 2015 & provisioning \\
\hline 35. & Notter et al. & 2012 & provisioning \\
\hline 36. & Nuppenau & 2014 & provisioning, cultural, supporting, regulating, payments \\
\hline 37. & Petz et al. & 2014 & provisioning, regulating \\
\hline 38. & Poppenborg and Koellner & 2014 & regulating \\
\hline 39. & Sabatier et al. & 2013 & supporting \\
\hline 40. & Schlüter et al. & 2009 & provisioning, regulating \\
\hline 41. & Smajgl et al. & 2015 & provisioning, payments \\
\hline 42. & Sun and Müller & 2013 & payments \\
\hline 43. & Swetnam et al. & 2011 & regulating \\
\hline 44. & Villa & 2009 & provisioning, regulating \\
\hline 45. & Watanabe and Ortega & 2014 & provisioning, regulating \\
\hline 46. & Zanchi et al. & 2014 & provisioning, regulating \\
\hline
\end{tabular}

